\title{
Study of Phytochemical, Antioxidant and Antimicrobial Activity of Artocarpus heterophyllus
}

Nita Thapa, Pratiksha Thapa, Jay Bhandari, Prasodhan Niraula, Nikita Shrestha, Bhupal G. Shrestha*

Department of Biotechnology, Kathmandu University, Dhulikhel, Nepal.

\begin{abstract}
In today's world, search for natural medicines is increasing as a result of drug resistance of pathogens and also due to negative consequences of antibiotic. Presence of phytochemicals, antioxidant potential and antimicrobial activity of Artocarpus heterophyllus was carried out in this study. Leaf of this plant was subjected to warm extraction with three different solvents namely methanol, aqueous methanol and ethyl acetate. Leaf extract showed the presence of coumarin, alkaloid, terpenoid in methanol solvent; tannin, coumarin, saponin in aqueous methanol extract and coumarin, terpenoids in ethyl acetate solvent. Further, antimicrobial activity was assessed through disc diffusion method with six pathological bacteria and two fungi strains in four different concentrations of plant extract. Largest ZOI of $16 \mathrm{~mm}$ was obtained against B. subtilis in $200 \mathrm{mg} / \mathrm{ml}$ concentration for ethyl acetate extract. Antioxidant potential was measured by DPPH (Diphenyl-2-picrylhydrazyl) assay. DPPH free radical Scavenging Activity was expressed in \% inhibition with L Ascorbic acid as standard and leaf extract in methanol showed the best activity.
\end{abstract}

Keywords: Phytochemical, Antioxidant, Antimicrobial, $\mathrm{IC}_{50}$, ZOI (Zone of Inhibition).

*Corresponding Author

Email: bgs@ku.edu.np

\section{Introduction}

In the written record, the study of herbs dates back over 5,000 years to the Sumerians, who created clay tablets with lists of hundreds of medicinal plants such as myrrh and opium [1]. The traditional use of herbs to prevent, treat and even cure various illnesses and diseases has largely been replaced by modern medicine. However, it has been estimated by World Health Organization (WHO) that 80 percent of the population of some Asian and African countries presently depend on traditional herbal medicine for their most basic health care needs. Also WHO notes that between $25-40 \%$ of pharmaceuticals drugs are derived from plants. It is also noted that $40-50 \%$ of medicines are direct or synthetic copies of plant ingredients. The use of medicinal plants offers poorer populations the ability to fight diseases at low costs. The use of traditional medicine and medicinal plants in most developing countries, as a normative basis for the maintenance of good health, has been widely observed [2]. Herbal medicine is still the mainstay of about $75-80 \%$ of the whole population, and the major part of traditional therapy involves the use of plant extract and their active constituents [3]. In recent years, antimicrobials derived from the plants have been receiving increasing attention as synthetic antibiotics have shown ineffectiveness against several pathogenic organisms due to increasing drug resistance [4]. Nepal is botanically rich in all the three levels of biodiversity which are species diversity, genetic diversity and habitat diversity. In Nepal, there are various plants with potent medicinal properties and have been used since ancient ages. Among the 7,000 species of medicinal plants recognized all over the world, more than 900 types of precious medicinal plants are said to be found in Nepal [5].

A. heterophyllus bark and fruit are medicinally used to treat sprains, fractures, diabetes and are also used for laxative effect of abdomen and to increase the breast milk production in nursing mothers [6]. In addition to the antimicrobial activity of $A$. heterophyllus, anti-inflammatory, antioxidant, anticholinergic, anti-diabetic, immune modulatory effect, inhibition of protease, oestrogen regulation and inhibition of melanin biosynthesis have also been reported through several pharmacological research investigations of the plant parts [7]. A. heterophyllus is a plant belonging to Moraceae family and is commonly referred to as 'Jackfruit' in English and 'Katahar' in Nepali. It is found to originate from 
Southeast Asia and is widely cultivated in tropical lowlands and are found to have distinct aroma. The bark, roots, leaves and fruit are found to contain medicinal properties and are widely used in various traditional and folk systems of medicine in order to treat a range of ailments.

\section{Materials and Methods}

\section{Sample preparation}

A. heterophyllus leaves were collected from Pachkhal, Nepal. The leaves were washed thoroughly under tap water and shade dried at room temperature (24$26^{\circ} \mathrm{C}$ ) and then pulverized by a mechanical grinder. The powder was then passed through a 40-mesh sieve and stored in a well closed container before its use.

\section{Solvent Extraction}

Warm extraction was done using Soxhlet apparatus using methanol and ethyl acetate as solvent. $6 \mathrm{gm}$ of the powdered sample was packed into the filter paper and were placed into the thimble of the Soxhlet apparatus. $250 \mathrm{ml}$ of methanol /ethyl acetate/aqueous methanol was added to the thimble. The apparatus was operated continuously for 3 days monitoring the circulation of water into the condenser. The soxhlet extract was then treated with hexane in order to remove chlorophyll pigment by the help of the separating funnel. The process was repeated until the chlorophyll pigment was completely extracted in hexane. Then the final extract was collected in Eppendorf tube after the extract was dried of solvent on water bath at $50^{\circ} \mathrm{C}$ [8]. Various concentrations were then made by dissolving in Dimethyl Sulfoxide (DMSO).

\section{Phytochemical screening}

Presence of phytochemicals were analyzed by following standard procedure which are as follows:

\section{A. Test for Basic Alkaloids (Mayer's Test)}

$5 \mathrm{ml}$ of extract was concentrated to yield a residue. Residue was dissolved in $3 \mathrm{ml}$ of $2 \%$ (v/v) HCL. 3 drops of Mayer's reagent were added. Appearance of the dull white precipitate indicated the presence of basic alkaloids.

\section{B. Test for coumarin}

4ml extract solution was taken. 1-2 drops of water (hot) was added. Volume was made half (for UV fluorescence). $10 \% \mathrm{NH}_{4} \mathrm{OH}$ was added to another half volume (for strong fluorescence). Presence of green fluorescence indicated the presence of coumarin.

\section{Test for Saponins}

$2 \mathrm{ml}$ extract was shaken vigorously for 30 seconds in a test tube. Persistence of thick forth even after 30 minutes indicated the presence of saponins.

\section{Test for Glycosides}

$2 \mathrm{ml}$ of extract was dried till $1 \mathrm{ml} .1-2 \mathrm{ml} \mathrm{NH}_{4} \mathrm{OH}$ was added and shaken. Appearance of cherish red color indicated the presence of glycosides.

\section{E. Test for Reducing Sugar (Fehling's Test)}

$1 \mathrm{ml}$ of extract was taken. $1 \mathrm{ml}$ distill water was added.5-8 drops of Fehling's solution (hot) was added. Presence of brick red precipitation indicated the presence of reducing sugar.

\section{F. Test for steroids}

$1 \mathrm{ml}$ extract was dissolved in $10 \mathrm{ml}$ chloroform. Equal volume of conc. $\mathrm{H}_{2} \mathrm{SO}_{4}$ was added by the side of test tube. Upper layer turned red and sulphuric acid layer turned yellow with green fluorescence. This indicated the presence of steroids.

\section{G. Test for Quinone}

$\mathrm{ml}$ of extract was taken.1ml of conc. $\mathrm{H}_{2} \mathrm{SO}_{4}$ was added. Formation of red color indicated the presence of quinone.

\section{H. Test for Terpenoids}

$1 \mathrm{ml}$ of extract was mixed with $2 \mathrm{ml}$ of chloroform. $3 \mathrm{ml}$ of conc. $\mathrm{H}_{2} \mathrm{SO}_{4}$ was added to form a layer. Reddish brown precipitate coloration at the interface formed indicated the presence of terpenoid.

\section{Antioxidant Assay}

Diphenyl-2-picrylhydrazyl (DPPH) radical scavenging activity was done for determining antioxidant activity.

\section{Preparation of DPPH solution}

DPPH solution of $100 \mu \mathrm{M}$ was prepared by dissolving $3.94 \mathrm{mg}$ of $\mathrm{DPPH}$ in $100 \mathrm{ml}$ of methanol. It was 
protected from light by covering the bottle with aluminum foil.

\section{Preparation of standard solution}

$10 \mathrm{mg} / \mathrm{ml}$ stock solution of Ascorbic acid was prepared and test solution of 1, 2, 3, 4, 5 and 10 $\mu \mathrm{g} / \mathrm{ml}$ of ascorbic acid was prepared from stock solution by dilution.

\section{Preparation of Test sample}

$10 \mathrm{mg}$ of plant extract was dissolved in $1 \mathrm{ml}$ of methanol to prepare stock solution of $10 \mathrm{mg} / \mathrm{ml}$. Test solution $1,2,3,4,5$ and $10 \mu \mathrm{g} / \mathrm{ml}$ was prepared from stock solution by dilution. Experiments were done in triplicate.

\section{Estimation of DPPH scavenging activity}

For this, $1 \mathrm{ml}$ methanol and $1 \mathrm{ml}$ DPPH solution were mixed as control. $2 \mathrm{ml}$ methanol was taken in Eppendorf tube as blank. $1 \mathrm{ml}$ ascorbic acid was mixed with $1 \mathrm{ml}$ DPPH as standard and $1 \mathrm{ml}$ plant extract was mixed with $1 \mathrm{ml} \mathrm{DPPH}$ as sample. All these mixtures were immediately kept in dark to prevent from light. After 30 minutes, absorbance was taken in 517nm.

\section{Antimicrobial Screening}

Agar Disc Diffusion Assay was performed to test antibacterial and antifungal activities [9]. Fungal strains Rhizopus, Aspergillus flavus and bacterial strains Pseudomonas aeruginosa, Bacillus subtilis, Bacillus thuringiensis, Escherichia coli, Proteus mirabilis were subjected to sensitivity test. Whatman Filter 1 disc $(6 \mathrm{~mm})$ was autoclaved and dipped in extract of various concentrations and introduced on the upper layer of agar plate earlier swabbed with microbial concentration with the help of inoculating loop. Standard antibiotic discs Chloramphenicol $30 \mu \mathrm{g}(\mathrm{C}$ 30) , Gentamicin $10 \mu \mathrm{g}$ (GEN 10), Ciprofloxacin $30 \mu \mathrm{g}$ (CF 30), Cefotaxime $30 \mu \mathrm{g}$ (CTX 30) and Tetracycline $30 \mu \mathrm{g}$ (TE 30) were used. The plates were incubated overnight at $37^{\circ} \mathrm{C}$. Microbial growth inhibition was determined by measuring the diameter of zone of inhibition (ZOI). Results of antimicrobial activity are expressed as average of triplicates.

\section{RESULTS}

In our study, when six gram of dried sample was used for extraction, aqueous methanol exhibited highest yield percentage i.e. $10.98 \%$ and least yield was given by methanol solvent i.e. $0.22 \%$. Ethyl acetate solvent gave yield of $4.68 \%$ when used as shown in Table 1.

Table 1: Yield Value of Artocarpus heterophyllus

\begin{tabular}{ccccc}
\hline S.N. & Solvent & $\begin{array}{l}\text { sample } \\
\text { loaded } \\
(\mathrm{gm})\end{array}$ & $\begin{array}{l}\text { Yield } \\
\text { amount } \\
(\mathrm{gm})\end{array}$ & $\begin{array}{l}\text { Yield } \\
\text { Percentage } \\
(\%)\end{array}$ \\
\hline 1 & $\begin{array}{c}\text { Ethyl } \\
\text { Acetate }\end{array}$ & 6 & 0.28 & 4.68 \\
2 & $\begin{array}{c}\text { Aqueous } \\
\text { Methanol }\end{array}$ & 6 & 0.66 & 10.98 \\
3 & Methanol & 6 & 0.013 & 0.22 \\
\hline
\end{tabular}

Extraction and characterization of several active phytocompounds from these green factories have given birth to some high activity profile drugs [10]. Secondary metabolites of plants serve as defense mechanisms against predation by many microorganisms, insects and herbivores [11]. Methanol extract showed presence of coumarin, steroids; ethyl acetate showed presence of coumarin, terpenoid whereas aqueous methanol showed presence of tannin, coumarin and saponin as shown in Table 2.

Table 2: Phytochemical screening

\begin{tabular}{llll}
\hline Phytochemicals & Methanol & $\begin{array}{l}\text { Ethyl } \\
\text { Acetate }\end{array}$ & $\begin{array}{l}\text { Aqueous } \\
\text { Methanol }\end{array}$ \\
\hline Alkaloids & + & - & - \\
Tannins & - & - & + \\
Reducing & - & - & - \\
sugar & & & \\
Coumarin & + & + & + \\
Glycosides & - & - & - \\
Quinone & - & - & - \\
Steroids & - & - & - \\
Terpenoids & + & + & - \\
Saponin & - & - & + \\
\hline
\end{tabular}


Table 3: Antimicrobial Assay

\begin{tabular}{|c|c|c|c|c|c|}
\hline \multirow[t]{2}{*}{ Solvent } & \multirow[t]{2}{*}{ Microorganism } & \multicolumn{4}{|c|}{ Extract Concentration (in mg/ml) and Zone of Inhibition (in mm) } \\
\hline & & $200 \mathrm{mg} / \mathrm{ml}$ & $100 \mathrm{mg} / \mathrm{ml}$ & $50 \mathrm{mg} / \mathrm{ml}$ & $25 \mathrm{mg} / \mathrm{ml}$ \\
\hline \multirow{8}{*}{ Methanol } & B. cereus & 11 & 9 & 7 & 7 \\
\hline & B. thuringiensis & 11 & 10 & 7 & 6.5 \\
\hline & E. coli & 6.5 & 6 & 6 & 6 \\
\hline & P. aeruginosa & 7 & 7 & 6.5 & 6.5 \\
\hline & P. mirabilis & 7.5 & 7 & $6 . .5$ & 6.5 \\
\hline & Rhizopus & 9 & 8 & 7 & 6.5 \\
\hline & A. flavus & 9 & 9 & 7.5 & 7 \\
\hline & B. subtilis & 9 & 7.5 & 7 & 6.5 \\
\hline \multirow{8}{*}{$\begin{array}{c}\text { Ethyl } \\
\text { Acetate }\end{array}$} & B. cereus & 11 & 7 & 6.5 & 6.5 \\
\hline & B. thuringiensis & 7 & 6.5 & 6.5 & 6.5 \\
\hline & E. coli & 8 & 7.5 & 7.5 & 6.5 \\
\hline & P. aeruginosa & 12 & 11 & 8 & 7 \\
\hline & P. mirabilis & 9 & 7.5 & 7 & 6.5 \\
\hline & Rhizopus & 8 & 7 & 6.5 & 6.5 \\
\hline & A. flavus & 9 & 8 & 7.5 & 7 \\
\hline & B. subtilis & 16 & 13 & 11 & 10 \\
\hline \multirow{8}{*}{$\begin{array}{l}\text { Aqueous } \\
\text { Methanol }\end{array}$} & B. cereus & 10 & 7.5 & 7.5 & 7.5 \\
\hline & B. thuringiensis & 6.5 & 6 & 6 & 6 \\
\hline & E. coli & 7.5 & 6.5 & 6.5 & 6.5 \\
\hline & P. aeruginosa & 6.5 & 6.5 & 6.5 & 6 \\
\hline & P. mirabilis & 7.5 & 6.5 & 6 & 6 \\
\hline & Rhizopus & 9 & 8 & 7 & 6.5 \\
\hline & A. flavus & 8 & 7 & 7 & 5.5 \\
\hline & B. subtilis & 9 & 7.5 & 6.5 & 6.5 \\
\hline
\end{tabular}

This finding is similar to the findings of Rawat et al [12]. Coumarin was present in all three extracts tested and it can be said that this plant's leaf exhibit blood-thinning, anti-fungicidal and anti-tumor activities. Presence of terpenoid is responsible for its aromatic properties whereas it also possesses medicinal industries [13]. Tannin is found to present in aqueous methanol extract which is naturally occurring plant polyphenols that have a characteristic binding and precipitating proteins. Phytochemical screening from other research confirmed the presence of phytosterols,

Table 4: Zone size interpretative standards for selected antimicrobial discs (CTX ${ }^{30}$, GEN10, $\mathrm{CF}^{30}, \mathrm{C}^{30} \mathrm{TE}^{30}$ ) and their observed ZOI during experiment

\begin{tabular}{|c|c|c|c|c|c|c|c|c|}
\hline \multirow[t]{2}{*}{ Antibiotics } & \multicolumn{8}{|c|}{ ZONE OF INHIBITION (mm) } \\
\hline & B. cereus & E. coli & B. thuringiensis & P. mirabilis & Rhizopus & A. flavus & P. aeruginosa & B. sub tilis \\
\hline CTX30 & 18 & 20 & 11 & 20 & 23 & 26 & 34 & 34 \\
\hline GEN10 & 24 & 25 & 20 & 14 & 26 & 23 & 34 & 22 \\
\hline $\mathrm{CF}^{30}$ & 30 & 25 & 23 & 20 & 32 & 30 & 47 & 32 \\
\hline $\mathrm{C}^{30}$ & 23 & 29 & 24 & 12 & 33 & 36 & 30 & 24 \\
\hline $\mathrm{TE}^{30}$ & 31 & 24 & 25 & 11 & 25 & 26 & 34 & 31 \\
\hline
\end{tabular}

antibacterial and anti-cancer properties. This plant can also reduce problem of cholesterol as presence of steroid is noted. Saponin is only present in aqueous methanol extract and it can also contribute to lowering of blood cholesterol and inhibition of cancer cell growth. Saponin containing plants are used as traditional medicines, especially in Asia and are intensively used in food, veterinary and anthraquinone, terpenoids, phenols, glycosides, flavonoids and diterpenes in both of the trees i.e. Artocarpus heterophyllus and Artocarpus altilis [14]. The antioxidant activity of tannins results from their free radical and reactive oxygen species-scavenging properties, as well as the chelation of transition metal ions that modify the oxidation process [15]. 
Table 5: Antioxidant Activity

\begin{tabular}{ccccccc}
\hline \multirow{2}{*}{$\begin{array}{c}\text { Concentration } \\
(\mu \mathrm{g} / \mathrm{ml})\end{array}$} & \multicolumn{2}{c}{ Methanol } & \multicolumn{2}{c}{ Ethyl Acetate } & \multicolumn{2}{c}{ Aqueous Methanol } \\
\cline { 2 - 7 } & Ascorbic acid & Leaf extract & Ascorbic acid & Leaf extract & Ascorbic acid & Leaf extract \\
\cline { 2 - 7 } & 8.07 & 6.63 & 14.37 & 3.26 & 11.38 & 10.41 \\
2 & 18.45 & 11.93 & 17.69 & 6.52 & 15.78 & 14.13 \\
3 & 25.81 & 15.25 & 22.54 & 8.01 & 31.67 & 18.15 \\
4 & 35.46 & 20.68 & 28.72 & 10.95 & 41.42 & 22.76 \\
5 & 44.25 & 28.03 & 34.66 & 14.43 & 44.19 & 26.63 \\
10 & 89.25 & 61.84 & 38.45 & 17.86 & 94.04 & 47.17 \\
\hline
\end{tabular}
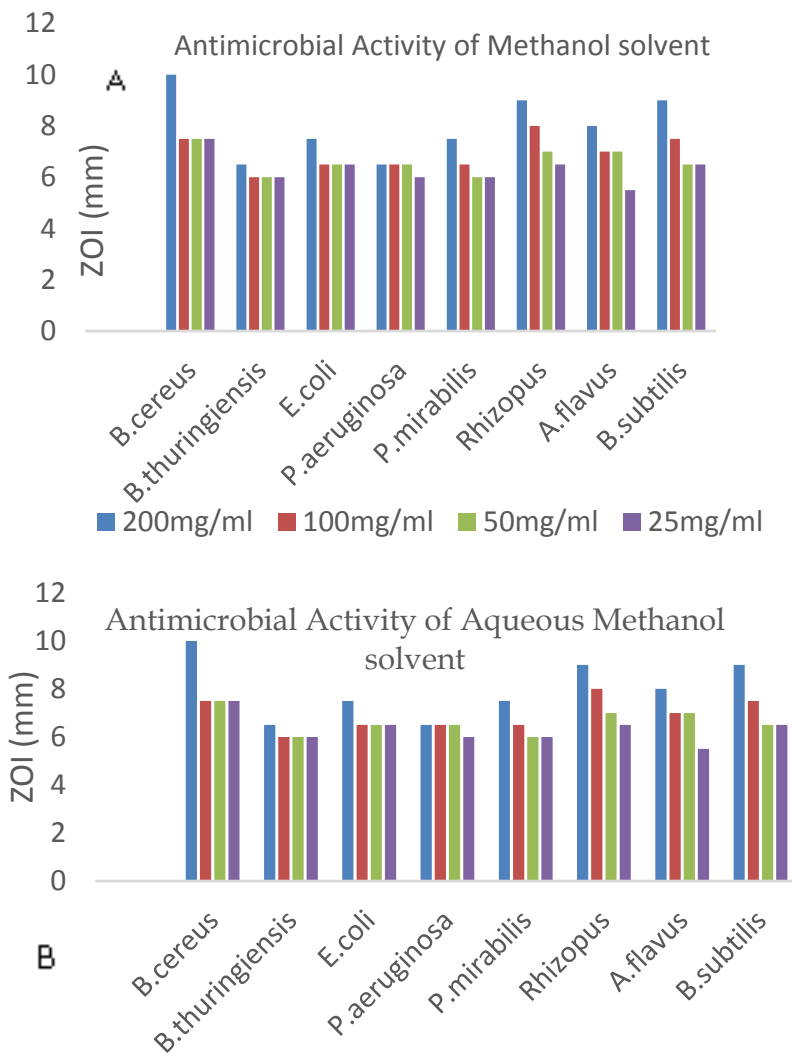

$\square 200 \mathrm{mg} / \mathrm{ml} \square 100 \mathrm{mg} / \mathrm{ml} \square 50 \mathrm{mg} / \mathrm{ml} \square 25 \mathrm{mg} / \mathrm{ml}$
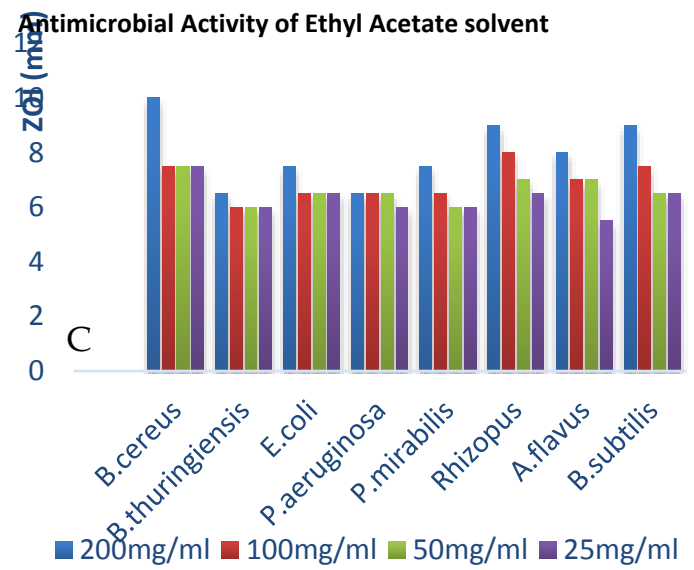

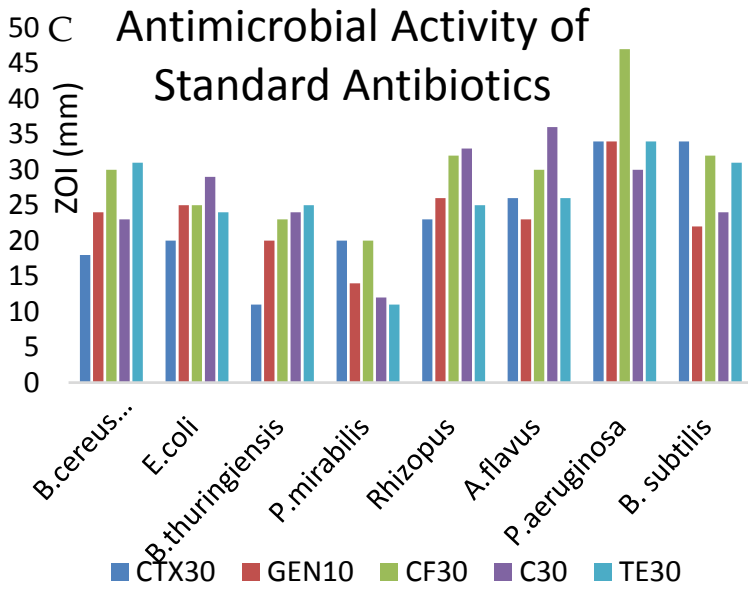

Figure 1: A, B and C are antimicrobial activity of extract prepared in methanol, aqueous methanol and ethyl acetate. Figure D represent antimicrobial activity of the standard antibiotics with 8

Antimicrobial assay was performed by agar disc diffusion method by using six bacterial strains and two fungal strains. This activity was assessed by measuring the diameter of ZOI of four concentrations used as shown in Table 3. The obtained ZOI of standards for selected antimicrobial discs is shown in Table 4 . Largest ZOI of $16 \mathrm{~mm}$ was obtained against B. subtilis in ethyl acetate extract, whereas $11 \mathrm{~mm}$ ZOI was largest in methanol extract obtained against $B$. cereus. Antimicrobial activity was comparatively better in ethyl acetate extract in comparison to methanol and aqueous methanol extract.

Besides this, antibacterial activity was higher than antifungal activity as largest ZOI of $9 \mathrm{~mm}$ is obtained against fungi Rhizopus and A. flavus. Also ZOI was largest in $200 \mathrm{mg} / \mathrm{ml}$ and least in $25 \mathrm{mg} / \mathrm{ml}$ concentration, showing a dose dependent response. Clinical microbiologists are showing interest in the 


\section{Antioxidant Activity (Methanol)}

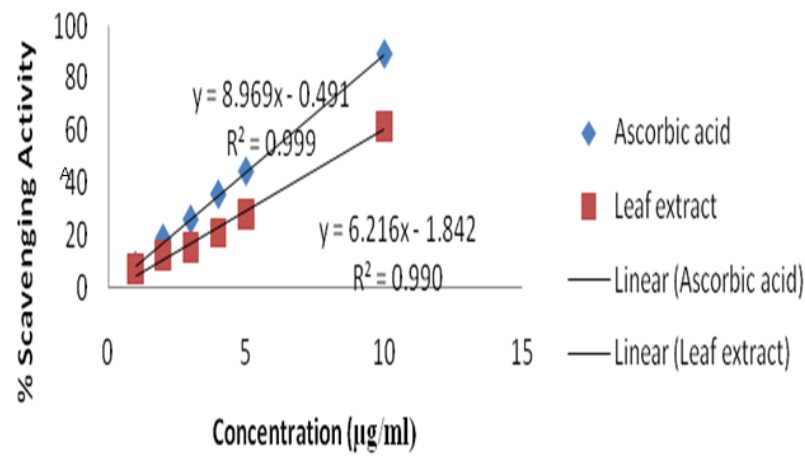

IC50 value of ascorbic acid $=5.62 \mu \mathrm{g} / \mathrm{ml}$

IC50 value of Artocarpus heterophyllus $=8.33 \mu \mathrm{g} / \mathrm{ml}$

Antioxidant Activity (Ethyl Acetate)

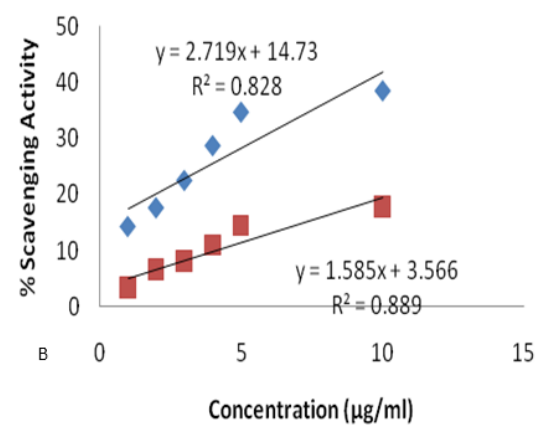

IC50 value of ascorbic acid $=12.96 \mu \mathrm{g} / \mathrm{ml}$

IC50 value of Artocarpus heterophyllus $=29.29 \mu \mathrm{g} / \mathrm{ml}$

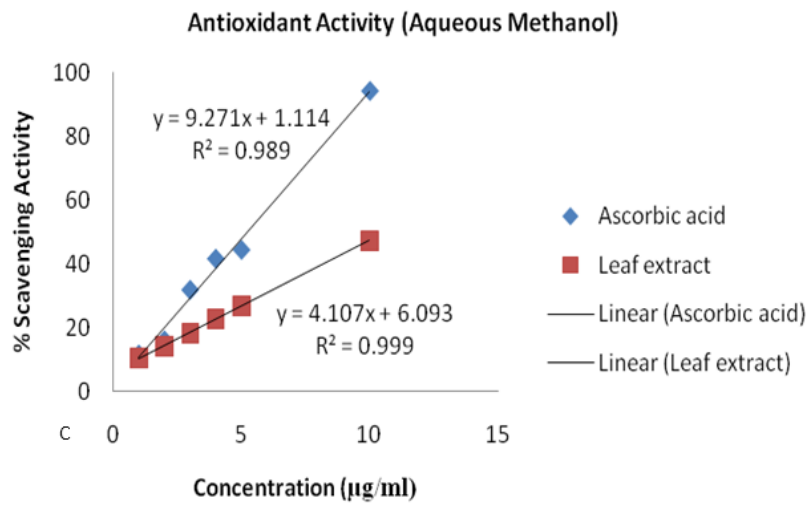

IC50 value of Ascorbic acid $=5.27 \mu \mathrm{g} / \mathrm{ml}$

IC50 value of Artocarpus heterophyllus $=10.69 \mu \mathrm{g} / \mathrm{ml}$

Figure 2: A, B and C represents antioxidant activity of methanol, ethyl acetate, aqueous methanol respectively.

topic of antimicrobial plant extracts as they believe that these phytochemicals will find their way as alternate to antimicrobial drugs as those prescribed by physicians. Also several of these plant extracts are already being tested in humans and this is probably because of increased public awareness of problems with the over prescription and misuse of traditional antibiotics. Also nowadays multiple drug resistance has developed due to the indiscriminate use of commercial antimicrobial drugs commonly used in the treatment of infectious disease [16].

DPPH stable free radical method is an easy, rapid and sensitive way to survey the antioxidant activity of a specific compound or plant extracts [17]. In our study, effective antioxidant activity was shown by methanol extract where $\mathrm{IC}_{50}$ value for ascorbic acid was $5.62 \mu \mathrm{g} / \mathrm{ml}$ and leaf extract showed value of 8.33 $\mu \mathrm{g} / \mathrm{ml}$ as shown in Table 5 . Similarly, $\mathrm{IC}_{50}$ value for ascorbic acid was $12.96 \mu \mathrm{g} / \mathrm{ml}$ and leaf extract showed value of $29.29 \mu \mathrm{g} / \mathrm{ml}$ when ethyl acetate was used as solvent. $\mathrm{IC}_{50}$ value for ascorbic acid was $5.27 \mu \mathrm{g} / \mathrm{ml}$ and leaf extract showed value of $10.69 \mu \mathrm{g} / \mathrm{ml}$ when aqueous methanol was used as solvent. Among three solvents used for the study, methanol extract showed best the antioxidant activity. So, the leaf extract of the plant could have some anti-cancer activity as has been earlier reported for Ashwagandha [18, 19].

\section{Conclusion}

We have been able to show that the leaf of $A$. heterophyllus contains presence of different phytochemicals that have potential health benefits. Extraction efficiency of leaf extract was higher in aqueous methanol solvent. Preliminary study indicated the presence of phytochemicals which can further be studied to explore medicinal properties. The plant extract also showed more antibacterial activity than antifungal activity against major pathogens. Methanol extract showed effective antioxidant activity in comparison to other solvent used in this study. Further, these can be subjected to isolation of the therapeutic antimicrobials which can be beneficial to mankind.

\section{Acknowledgement}

We would like to express our deep gratitude to Kathmandu University Biotechnology Department for providing us work space and necessary guidance for the successful completion of this research work. 


\section{References}

1. Sumner J: The natural history of medicinal plants. Timber press. 2000.

2. Culture and Health, Orientation Texts - World Decade for Cultural Development 1988 - 1997, Document CLT/DEC/PRO - 1996, Paris, France, pg. 129.

3. Akerele O: Summary of WHO Guidelines for the Assessment of Herbal Medicines Herbal Gram. 1993, 22: 13-28.

4. Akgul C, Saglikoglu G: Antibacterial activity of crude methanolic extract and its fractions of aerial parts of Anthemis tinctoria. Ind J Biochem Biophy. 2005, 42: 395-397.

5. Manandhar NP: Plants and People of Nepal. Timber Press. USA. 2000: 50p.

6. Fernando S: Herbal food and medicines in Sri Lanka. New Delhi. (Original work published in 1982).2003.

7. Jitendra R, Kalpana S, Shweta S, Kumar M S, Manish B: Artocarpus heterophyllus (jackfruit) potential unexplored in dentistry- an overview. UJP. 2014, 3(1): 50-55.

8. Shrestha $\mathrm{P}$ et al: Phytochemical screening, antimicrobial activity and cytotoxicity of Nepalese medicinal plants Swertia chirayita and Dendrobium amoenum. NJB 3.1. 2015 : 48-57.

9. Lamichhane B, Adhikari S, Shrestha P, Shrestha B G: Study of phytochemical, antioxidant, antimicrobial and anticancer activity of Berberis Aristata. J Trop Life Sci. 2014, 4(1): 01-07.

10. Mandal V, Mohan Y, Hemalatha S: Microwave assisted extraction - an innovative and promising extraction tool for medicinal plant research. Pharmacognosy Reviews. 2007, 1(1):7-18.

11. Lutterodt $G D$, Ismail $A$, Basheer $R H$, Baharudin $H$ M: Antimicrobial effects of Psidium guajava extracts as one mechanism of its antidiarrhoeal action. Malaysian J Med Sci. 1999, 6(2): 17-20.

12. Rawat A, Mahajan S, Gupta A, Agnihotri R K, Wahi $\mathrm{N}$, Sharma R: Detection of toxigenic fungi and mycotoxins in some stored medicinal plant samples. IJASBT. 2014, 2(2): 211-216.

13. Hostettmann $K$, Marston A: Chemistry and Pharmacology of Natural Products, Saponin. 1995.

14. Suman R, Arti T: Evaluation of phytochemical and antimicrobial effect of Artocarpus heterophyllus leaves extracts. J Pharm Sci. 2014.

15. Serrano J, Puupponen-Pimia R, Dauer A, Aura A, Saura-Calixto F: Tannins: current knowledge of food sources, intake, bioavailability and biological effects. Mol Nutr Food Res. 2009, 53:310-329.

16. Joshi B, Lekhak S, Sharma A: Antibacterial property of different medicinal plants: Ocimum sanctum,
Cinnamomum zeylanicum, Xanthoxylum armatum and Origanum majorana. Kathmandu university journal of science, engineering and technology. 2009, 5(1): 143-150.

17. Koleva I I, van Beek T A, Linssen J P, Groot A D, Evstatieva L N: Screening of plant extracts for antioxidant activity: a comparative study on three testing methods. Phytochem anal. 2002, 13(1): 8-17.

18. Widodo N , Kaur K, Shrestha B G, Takagi Y, Ishii T, Wadhwa R, Kaul S C: Selective Killing of Cancer Cells by Leaf Extract of Ashwagandha: Identification of a Tumor-Inhibitory Factor and the First Molecular Insights to Its Effect. Clin Cancer Res. 2007, 13(7): 2298-2306.

19. Widodo N, Takagi Y, Shrestha B G, Ishii I, Kaul S C, Wadhwa R: Selective killing of cancer cells by leaf extract of Ashwagandha: Components, activity and pathway analyses. Cancer Letters. 2008, 262: 37-47. 